\title{
Lawsonia Inermis: Its Anatomy and its Antimalarial, Antioxidant and Human Breast Cancer Cells MCF7 Activities
}

\section{Fatiha El Babili ${ }^{1,3 *}$, Alex Valentin ${ }^{2}$ and Christian Chatelain ${ }^{1}$}

${ }^{1}$ Faculté des Sciences Pharmaceutiques de Toulouse-Laboratoire de Botanique-Mycologie-Faculté de Pharmacie, 35 ch. des Maraîchers - F- 31062 Toulouse, France ${ }^{2}$ Laboratoire de Pharmacochimie des Substances Naturelles et Pharmacophores Redox, UMR 152, UPS, Université de Toulouse, 118 Route de Narbonne, F-31062 Toulouse Cedex 9, France

${ }^{3}$ Laboratoire des Interactions Moléculaires et Réactivité Chimique et Photochimique UMR CNRS 5623, Université de Toulouse, 118 Route de Narbonne, F-31062 Toulouse Cedex 9, France

\begin{abstract}
Anatomical features were highlighted to improve its identification, because although henna has some benefits, it has a wide spectrum of adverse effects from contact dermatitis to severe angioneurotic oedema and haemolysis. Serial extractions in petroleum ether, ethyl acetate, ethanol and water were performed on leaves of Lawsonia inermis and were studied. In these extracts, different chemical families were measured such as polyphenols (Gallic acid equivalent 71.7-129.6 g/Kg), tannins (Catechin equivalent 31.3-477.9 g/Kg), antocyanins (Cyanidin equivalent $0.75-5.48 \mathrm{mg} / \mathrm{Kg}$ ) and flavonoids (Quercetin equivalent $16.2-85.6 \mathrm{~g} / \mathrm{Kg}$ ).
\end{abstract}

This present study reports ABTS/DPPH assay and antimalarial activity. We also checked activity against human breast cancer cells MCF7.

The best extract with an antioxidant activity $\left(\mathrm{IC}_{50}=6.9 \pm 0.1 \mathrm{mg} / \mathrm{L}\right)$ was obtained by ethanol. We found an antimalarial activity of the petroleum ether extract $(27 \mathrm{mg} / \mathrm{L})$ of henna. Henna extracts showed activity against human breast cancer cells (MCF7) with the ethyl acetate extract $(27 \mathrm{mg} / \mathrm{L})$ and petroleum extract $(22 \mathrm{mg} / \mathrm{L})$.

Keywords: Lawsonia inermis; Antioxidant activity; Antimalarial activity; Cytotoxicity MCF7

\section{Introduction}

Lawsonia inermis L. (= L. alba Lamk.), belonging to the Lythraceae family, is a very widespread medicinal plant and natural dye in the world. This herb which has interesting dyeing properties was used traditionally for centuries in Asia, in Africa for dyeing hair and painting skin and nails. Since 1890, it has been widely distributed to Europe and nowadays available in worldwide market as ingredient in many hair dyes and hair-care products. Lawsonia. inermis, also called "henna", contains many kinds of chemical compounds, such as coumarin, quinones, flavonoids etc. and has stronger physiological activity. Due to its natural and harmless characters, the Henna is used as a kind of natural dye, and is used as a raw material for natural hair dyes. In addition, Henna can be used as dyes for textile and tattoo material. The medicinal value of $\mathrm{L}$. inermis is very high and it is used for treatments of headache, jaundice, leprosy [1]. In addition, Henna was shown as an unusual cause of children suicide [2].

The phytochemistry of henna was largely studied and revealed interesting information. Already in 1920 the dye principle was known. Lawsone, $\mathrm{C}_{10} \mathrm{H}_{6} \mathrm{O}_{3}$, the colouring matter contained in henna leaves, is fixed well by wool, silk and tenaciously by the skin [3]. In 1973, four fractions with antibacterial activity were isolated by thin-layer chromatography of the ethanol extract of Lawsonia inermis leaves. 3 of which were identified as gallic acid [149-91-7], lawsone (2-hydroxy1,4-naphthoquinone)(I) [83-72-7], and 1,4-naphthoquinone [130-154] [4].

Then in 1976, a coumarin, lacoumarin, was isolated from L. inarmis. It was then the turn of xanthones; two xanthones isolated from L. inermis were characterized as 1,3-dihydroxy-6,7-dimethoxyxanthone and 1-hydroxy-3,6-diacetoxy-7-methoxyxanthone and named laxanthone I and II, respectively. Another xanthone, named laxanthone III was identified from chemical and spectral data [5].
Apigenin-7-glucoside, apigenin-4'-glucoside, luteolin-7-glucoside, and luteolin-3'-glucoside were isolated from leaf extracts of $L$. innermis. Its methanol extract yielded $\beta$-sitosterol, stigmasterol and 1,2-dihydroxy-4-glucosyloxynaphthalene. The leaves of $L$. inermis yielded luteolin, acacetin-7-O-glucoside, glucoside of $\beta$-sitosterol [6]. Two pentacyclic triterpenes isolated from the bark of $L$. inermis (henna) were identified as 3 $\beta, 30$-dihydroxylup-20(29)-ene (hennadiol) and (20S)-3 $\beta, 30$-dihydroxylupane [6].

In 1992, a sterol, namely lawsaritol, was isolated from the roots of $L$. inermis and elucidated as $24 \beta$-ethylcholest- 4 -en-3 $\beta$-ol and from the stem bark of $L$. inermis 3-methylnonacosan-1-ol [7]. The methanol extract of the defatted $L$. inermis seeds has led to the isolation of two triterpenoids lawnermis acid and its methyl ester [8]. Two pentacyclic triterpenoids have been isolated from the aerial parts of Lawsonia alba. The structures of the new constituents, named as lawsonic acid (I) and lawsonin (II) have been elucidated as 3 $\beta$-E-ferulyloxy-lup-20(29)en-28-oic acid and 3 $\beta$-E-ferulyloxy-urs-11-en-13 $\beta$-ol respectively, through spectroscopic studies [9].

The biological properties of henna were also studied as follows:

Crude ethanol extract of Lawsonia inermis L. produced anti-

*Corresponding author: Fatiha El Babili, Laboratoire de Botanique-Mycologie Faculté de Pharmacie, Université de Toulouse, 118 Route de Narbonne, F-31062 Toulouse Cedex 9, France, Tel: +33562259817; E-mail: fatiha el-babili@univ-tlse3.fr

Received November 26, 2012; Accepted January 23, 2013; Published January 25,2013

Citation: Babili FE, Valentin A, Chatelain C (2013) Lawsonia Inermis: Its Anatomy and its Antimalarial, Antioxidant and Human Breast Cancer Cells MCF7 Activities. Pharmaceut Anal Acta 4: 203. doi:10.4172/2153-2435.1000203

Copyright: $\odot 2013$ Babili FE, et al. This is an open-access article distributed unde the terms of the Creative Commons Attribution License, which permits unrestricted use, distribution, and reproduction in any medium, provided the original author and source are credited. 
inflammatory, analgesic, molluscicidal, antibacterial and antipyretic effects. The ethanolic extract of Lawsonia inermis leaves and lawsone tested for trypsin inhibitory activity showed an $\mathrm{IC}_{50}$ value of 64.87 and $48.6 \mathrm{microg} / \mathrm{ml}$, respectively [10]. Its ethanol leaf extract was active against a wide range of microbes, such as Staphylococcus, Streptococcus, Brucella and Salmonella, but was inactive against Pseudomonas aeruginosa and Candida albicans [4].

Its ethyl acetate extracts exhibit cytotoxic activity [11]. In fact, Isoplumbagin isolated from the air-dried stem bark of Lawsonia inermis exhibited cytotoxic activity (against melanoma and colon cancer cell lines as well as against several of the non-small cell lungs, colon, CNS and renal cell lines) [12].

As we can see, this plant presents strong potential. That is why we seek to complement the knowledge of henna with chemical and biological studies. The aim of our work on Henna was to study to study its anatomical features, the chemical composition of its extracts in the chemicals families such as polyphenols, tannins, antocyanins and flavonoids. The activity of Henna extracts was also evaluated as an antioxidant and anti-malarial. Finally, the toxicity against cancer cells of human breast (MCF7) was also studied for these samples.

\section{Materials and Methods}

\section{Plant material}

Lawsonia inermis L. collected in Morocco during 2009. Voucher specimens of leaves identified by Professor C. Chatelain and deposited at the herbarium of the Faculty of Pharmacy in Toulouse.

\section{Preparing slides}

Observations are based on microscopic studies of sectioned and stained material of tissues.

Transverse sections are prepared with a sliding microtome (MSE) and stained in alun carmine-green combination or Mirande reagent [13] during 2 to 3 minutes then washed with water. Following staining, the transverse sections are mounted on glass slides using glycerine gel. Powder observations were made using Chloral hydrate solution $\mathrm{R}$ [14]. Observations were made with a LEICA Microsystems DMLB microscope, and pictures were taken with Digital Camera Power Shot S40 CANON photo-micrographic system. For the description we have used some help books [15].

\section{Preparation of extracts}

Ground leaves from lawsonia (80 g), placed in an open column chromatography, was first defatted with petroleum ether $(0.8 \mathrm{~L})$ at ambient pressure and temperature. After removal of petroleum ether under reduced pressure, a dried extract obtained as green residue, with an extraction yield of $1.12 \%$. Then, the firstly lixiviate oregano powder was lixiviate with ethyl acetate $(0.8 \mathrm{~L})$. After removal of ethyl acetate under reduced pressure, a dried extract was obtained as white powder, slightly coloured in yellow, with an extraction yield of $1.23 \%$. Finally, the last lixiviation was made with ethanol $(1.2 \mathrm{~L})$. After removal of ethanol under reduced pressure, a dried extract obtained as brown powder with an extraction yield of $15 \%$. For the decoction, $50 \mathrm{~g}$ of henna powder were extracted with boiling water $(0.5 \mathrm{~L})$ during $30 \mathrm{~min}$. After removal of water by lyophilisation, brown powder was obtained with an extraction yield of $12.2 \%$.

\section{Chemicals}

All chemicals used were of analytical reagent grade. All reagents purchased from Sigma-Aldrich, Fluka (Saint-Quentin France).

\section{Total amount of phenolic compounds}

The total phenolic amount of each extract was determined by the Folin-Ciocalteu method [16]. A diluted solution of each extract $(0.5$ $\mathrm{mL})$ was mixed with Folin Ciocalteu reagent $(0.2 \mathrm{~N}, 2.5 \mathrm{~mL})$. This mixture was allowed to stand at room temperature for $5 \mathrm{~min}$ and then sodium carbonate solution $(75 \mathrm{~g} / \mathrm{L}$ in water, $2 \mathrm{~mL})$ was added. After $1 \mathrm{~h}$ of incubation, the absorbance was measured at $765 \mathrm{~nm}$ against blank using a Helios spectrophotometer (Unicam, Cambridge, UK). A standard calibration curve was plotted using gallic acid (0-300 mg/L). Results were expressed as $\mathrm{g}$ of gallic acid equivalents (GAE)/Kg of dry mass.

\section{Condensed tannin content}

Catechins and proanthocyanidins reactive with vanillin were analyzed by the vanillin method [17]. One milliliter $(1 \mathrm{~mL})$ of each extract solution was mixed in a test tube with $2 \mathrm{~mL}$ of vanillin (1\% in 7 $\mathrm{MH}_{2} \mathrm{SO}_{4}$ ) in an ice bath. Then the mix was incubated at $25^{\circ} \mathrm{C}$. After 15 minutes, the solution absorbance was read at $500 \mathrm{~nm}$. Concentrations were calculated as $\mathrm{g}$ catechin equivalents $(\mathrm{CE}) / \mathrm{Kg}$ dry mass from a calibration curve.

\section{Total flavonoids determination}

The total flavonoids were estimated according to the Dowd method as adapted by Arvouet-Grand [18]. A diluted methanolic solution (4 $\mathrm{mL}$ ) of each extract was mixed with a solution $(4 \mathrm{~mL})$ of aluminium trichloride $\left(\mathrm{AlCl}_{3}\right)$ in methanol (2\%). The absorbance was read at 415 $\mathrm{nm}$ after 15 minutes against a blank sample consisting of a methanol (4 $\mathrm{mL})$ and extract $(4 \mathrm{~mL})$ without $\mathrm{AlCl}_{3}$. Quercetin was used as reference compound to produce the standard curve, and the results were expressed as $\mathrm{g}$ of quercetin equivalents $(\mathrm{QE}) / \mathrm{Kg}$ of dry mass.

\section{Determination of total anthocyanin content}

Total anthocyanin content was measured with the $\mathrm{pH}$ differential absorbance method, as described by Cheng and Breen [19]. Briefly, absorbance of the extract was measured at 510 and $700 \mathrm{~nm}$ in buffers at pH 1.0 (hydrochloric acid-potassium chloride, $0.2 \mathrm{M}$ ) and 4.5 (acetate acid-sodium acetate, $1 \mathrm{M}$ ). The wavelength reading was performed after 15 minutes of incubation. Anthocyanin content was calculated using a molar extinction coefficient $(\varepsilon)$ of 29600 (cyanidin-3-glucoside) and absorbance of $\mathrm{A}=\left(\left(\mathrm{A}_{510}-\mathrm{A}_{700}\right)_{\mathrm{pH} 1.0}-\left(\mathrm{A}_{510}-\mathrm{A}_{700}\right)_{\mathrm{pH}}\right.$..5 $)$. Results were expressed as mg cyanidin-3-glucoside equivalent (C3GE) / Kg of dry mass.

\section{Free radical scavenging activity: DPPH test}

Antioxidant scavenging activity was studied using 1,1-diphenyl-2picrylhydrazyl free radical (DPPH) as described by Blois [20] with some modifications; $1.5 \mathrm{~mL}$ of various dilutions of the test materials (essential oil or plant extracts) were mixed with $1.5 \mathrm{~mL}$ of a $0.2 \mathrm{mM}$ methanolic $\mathrm{DPPH}$ solution. After an incubation period of 30 minutes at $25^{\circ} \mathrm{C}$, the absorbance at $520 \mathrm{~nm}$, the wavelength of maximum absorbance of $\mathrm{DPPH}$, were recorded as $\mathrm{A}_{\text {(sample), }}$ using a Helios spectrophotometer (Unicam, Cambridge, UK). A blank experiment was also carried out applying the same procedure to a solution without the test material and the absorbance was recorded as $\mathrm{A}_{\text {(blank) }}$. The free radical-scavenging activity of each solution was then calculated as percent inhibition according to the following equation:

$\%$ inhibition $=100\left(\mathrm{~A}_{\text {(blank) }}-\mathrm{A}_{\text {(sample) }}\right) / \mathrm{A}_{\text {(blank) }}$

Antioxidant activity of essential oil or extracts was expressed as 
$\mathrm{IC}_{50}$, defined as the concentration of the test material required to cause a 50\% decrease in initial DPPH concentration. Ascorbic acid was used as a standard. All measurements were performed in triplicate.

\section{ABTS radical-scavenging assay}

The radical scavenging capacity of the samples for the ABTS (2,2'-azinobis-3-ethylbenzothiazoline-6-sulphonate) radical cation was determined as described by Re et al. [21]. ABTS was generated by mixing a $7 \mathrm{mM}$ of ABTS at $\mathrm{pH} 7.4\left(5 \mathrm{mM} \mathrm{NaH}_{2} \mathrm{PO}_{4}, 5 \mathrm{mM} \mathrm{Na}_{2} \mathrm{HPO}_{4}\right.$ and $154 \mathrm{mM} \mathrm{NaCl}$ ) with $2.5 \mathrm{mM}$ potassium persulfate (final concentration) followed by storage in the dark at room temperature for $16 \mathrm{~h}$ before use. The mixture was diluted with ethanol to give an absorbance of 0.70 \pm 0.02 units at $734 \mathrm{~nm}$ using a spectrophotometer. For each sample, diluted methanol solution of the sample $(100 \mu \mathrm{L})$ was allowed to react with fresh ABTS solution $(900 \mu \mathrm{L})$, and then the absorbance was measured 6 minutes after initial mixing. Ascorbic acid was used as a standard and the capacity of free radical scavenging was expressed by $\mathrm{IC}_{50}(\mathrm{mg} / \mathrm{L})$ values calculated, denoting the concentration required to scavenge $50 \%$ of ABTS radicals. The capacity of free radical scavenging $\mathrm{IC}_{50}$ was determined using the same previously used equation for the DPPH method. All measurements were performed in triplicate.

\section{Assays on Plasmodium falciparum in vitro}

P. falciparum FcB1-Columbia strain (chloroquine-resistant: $\mathrm{IC}_{50}$ for chloroquine: $186 \mathrm{nM}$ ) was cultured continuously according to Trager and Jensen [22] with modifications described by Benoit et al. [23]. The $\mathrm{IC}_{50}$ value for chloroquine was checked every 2 months, and we observed no significant variations. The parasites were maintained

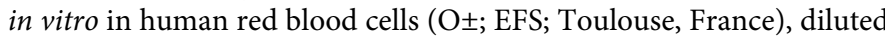
to $4 \%$ hematocrit in RPMI 1640 medium (Lonza; Emerainville, France) supplemented with $25 \mathrm{mM}$ Hepes and $30 \mathrm{mM} \mathrm{NaHCO}_{3}$ and complemented with $7 \%$ human $\mathrm{AB}+$ serum (EFS). Parasites cultures were synchronized by $\mathrm{D}$-sorbitol lysis ( $5 \%$ of $\mathrm{D}$-sorbitol in sterile water; D-sorbitol) as reported by Lambros and Vanderberg [24]. The antiplasmodial activities (essential oil, plant extracts) were evaluated by a radioactive micromethod derived from that of Desjardins et al. [25] with the modifications reported by Munoz et al. [26]. Tests were performed in triplicate in 96-well culture plates (TPP) with cultures mostly at ring stages (synchronisation interval, $16 \mathrm{~h}$ ) at 0.5 $1 \%$ parasitemia (hematocrit, $1.5 \%$ ). Parasite culture was incubated with each sample at growing dilution for $48 \mathrm{~h}$. Parasite growth was estimated by $\left({ }^{3} \mathrm{H}\right)$-hypoxanthine (Perkin-Elmer; Courtaboeuf, France) incorporation, which was added to the plates $24 \mathrm{~h}$ before freezing. After $48 \mathrm{~h}$ incubation, plates were frozen-defrosted and each well was harvested on a glass fiber filter. Incorporated $\left({ }^{3} \mathrm{H}\right)$-hypoxanthine was then determined with a betacounter (1450-Microbeta Trilux; WallacPerkin Elmer). $\mathrm{IC}_{50}$ values were determined by linear least square regression analysis. The control parasite culture, free from any sample, was referred to as $100 \%$ growth. $\mathrm{IC}_{50}$ were determined graphically in concentration versus percent inhibition curves. Chloroquine diphosphate was used as positive control. The antimalarial activity of samples was expressed as their $50 \%$ inhibitory concentrations $\left(\mathrm{IC}_{50}\right)$, representing the concentration of drug that induced a decrease of $50 \%$ in the parasitaemia compared to the positive control culture referred to as $100 \%$ parasitaemia. The antimalarial activities of plant extracts can be classified as follow: very active if $\mathrm{IC}_{50}<5 \mathrm{mg} / \mathrm{L}$, active if $\mathrm{IC}_{50}$ between 5 and $50 \mathrm{mg} / \mathrm{L}$, weakly active if $\mathrm{IC}_{50}$ between 50 and $100 \mathrm{mg} / \mathrm{L}$ and inactive if $\mathrm{IC}_{50}>100 \mathrm{mg} / \mathrm{L}$ [27]. For each sample, the CAR (cytotoxic/ antimalarial ratio) was calculated. It indicated the specificity of the antiplasmodial activity.

\section{Evaluation of the cytotoxicity against human breast cancer cells MCF7}

Sample cytotoxicity was studied on MCF7, a human breast cancer cell line. The cells were cultured in the same conditions as those used for P. falciparum, except for the $10 \%$ human serum, which was replaced by $10 \%$ foetal calf serum (Lonza). For the determination of cytotoxicity, cells were distributed in 96 -well plates at $3 \times 10^{4}$ cells/well in $100 \mu \mathrm{L}$, and then $100 \mu \mathrm{L}$ of culture medium containing samples at various concentrations were added. Cell growth was estimated by $\left({ }^{3} \mathrm{H}\right)$-hypoxanthine incorporation after $48 \mathrm{~h}$ incubation exactly as for the $P$. falciparum assay. The $\left({ }^{3} \mathrm{H}\right)$-hypoxanthine incorporation in the presence of sample was compared with that of control cultures without sample (positive control being doxorubicin) [28].

\section{Statistical analysis}

All data were expressed as means \pm standard deviations of triplicate measurements. The confidence limits were set at $\mathrm{P}<0.05$. Standard deviations (SD) did not exceed $5 \%$ for the majority of the values obtained.

\section{Results and Discussion}

Anatomical study of Lawsonia inermis shows the following elements.

\section{In stem}

Lawsonia inermis transverse section, stained with Mirande reagent shows various characteristic elements from the exterior to the interior.

An epidermis, with striated cuticle, made up of one layer of isodiametric cellulose thin-walled cells - A Phelloderm made up of a layer of cellulose thin-walled cells - A Cortical parenchyma made up of rounded thin-walled cells separated by meatuses and containing crystals of calcium oxalate. Its internal zone is invaded with laticiferous surrounded of acicular crystals of calcium oxalate. A pericycle zone made up of lignified thick-walled fibres clusters with narrow lumen - A continuous conducting ring made up of secondary phloem composed of cellulose tabular thin-walled-cells and wood composed of vessels, often aligned radially, and strongly lignified woody parenchyma. A PITH made up of polyhedral slightly sclerified thick-walled cells separated by meatuses, invaded by clusters of crystals of calcium oxalate (Figures 1-4).

\section{In leaf}

Lawsonia inermis (Figures 5 and 6) leaf transverse section, stained with Mirande reagent shows various characteristic elements from the superior face to the inferior face.

MIDRIB: An superior epidermis, with striated cuticle, made up of one layer of isodiametric thin-walled cells- A parenchyma made up of cellulose rounded thin-walled cells containing by place crystals of calcium oxalate. An arc shaped with vascular tissue composed with woody bundle and secondary phloem - An inferior cuticularized with anomocytic stomata, made up of one layer of cellulose isodiametric thin-walled cells;

LAMINA: A superior stomatiferous epidermis, with striated cuticle, made up of one layer of isodiametric (Figure 5), cellulosic thinwalled cells - An asymmetrical heterogeneous mesophyll made up of palisade and spongy parenchyma. In the middle, there are secondary vascular tissues with crystals of calcium oxalate (Figure 6). An inferior 
cuticularized epidermis, with anomocytic stomata, made up of one layer of cellulose isodiametric thin-walled cells;

Sampling of the inferior epidermis shows anomocytic stomata (Figure 7).

\section{Chemical composition}

As far as we know, this work is the first time that the chemical composition of aerial part of lawsonia inermis was evaluated (Table 1). Total amount of flavonoids, in henna ethyl acetate extract, was the higher $(85.6 \pm 3.1 \mathrm{~g} / \mathrm{kg}$ equivalent Quercetin), while ethyl acetate extract was the richest on polyphenols $(129.6 \pm 4.1 \mathrm{~g} / \mathrm{kg}$ eq Gallic acid). The antocyanins $(5.48 \pm 0.17 \mathrm{mg}$ de Cyaniding $/ \mathrm{kg})$ were present in higher content in ethanol extract. The tannins exist in all extracts with an amount between $31.3 \pm 0.8$ (decoction) to $477.9 \pm 12.9$ (ethyl acetate extract) eq Catechin ( $\mathrm{g} / \mathrm{Kg}$ dry). The chemical composition study of

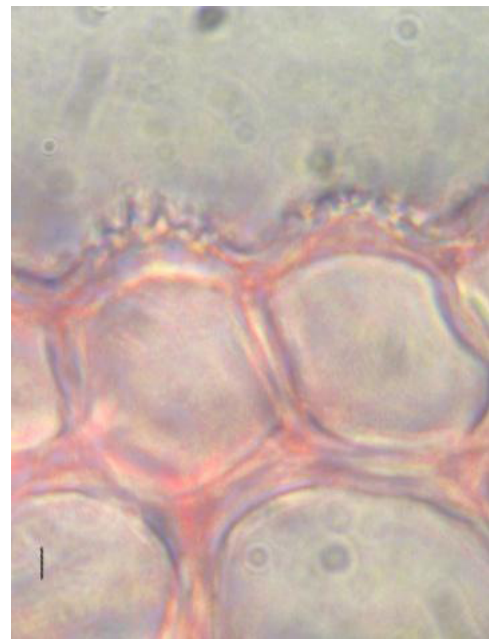

$(\times 100)$

Figure 1: Stem epidermis: Striated cuticle (SC), Epidermis (E).

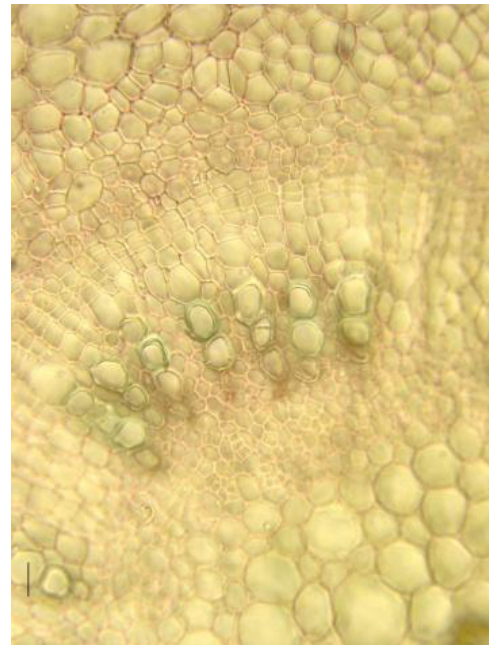

(× 20)

Figure 2: Vascular bundle: Cortical parenchyma $(\mathrm{CP})$ - Phloem $(\mathrm{PH})$ - Wood (W).

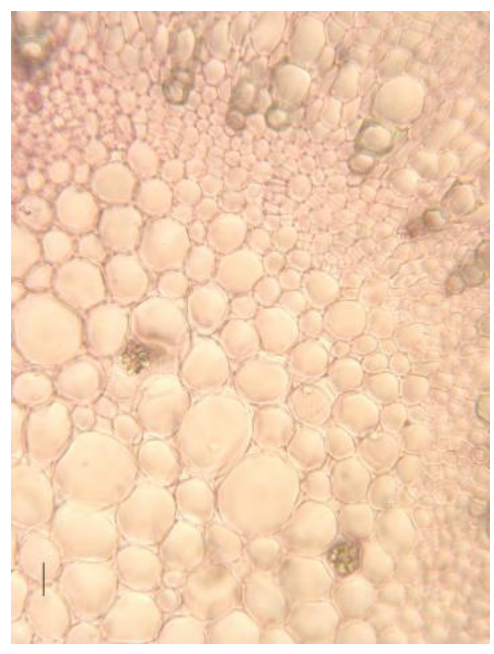

$(\times 20)$

Figure 3: Pith: Medullar parenchyma invaded by calcium oxalate crystals.

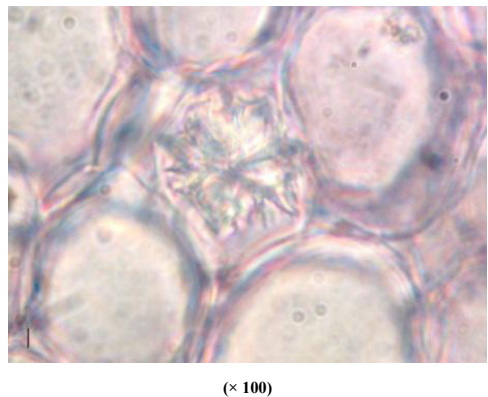

Figure 4: Stem: Crystals of calcium oxalate.

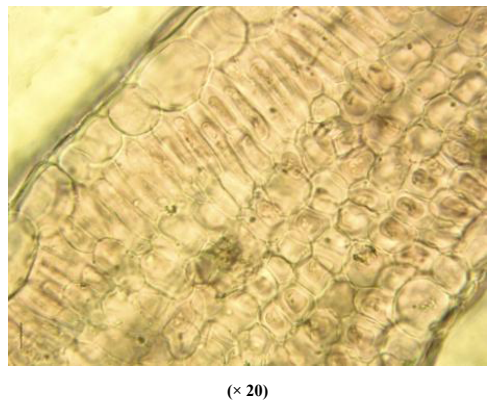

Figure 5: Lamina

henna extracts allows us to begin to understand its properties, pending clarifies this work by a structure-activity relationship.

\section{Antioxidant capacity}

In our study, the henna antioxidant activity (Table 2) showed for ethyl acetate extract an $\mathrm{IC}_{50}$ of $29.5 \pm 0.8 \mathrm{mg} / \mathrm{L}$ in $\mathrm{DPPH}$ radical scavenging assay and $\mathrm{IC}_{50}$ of $8.6 \pm 0.2 \mathrm{mg} / \mathrm{L}$ in ABTS radical scavenging assay. The ethanol extract exhibited an $\mathrm{IC}_{50}$ of $14.1 \pm 0.5 \mathrm{mg} / \mathrm{L}$ in DPPH and with $\mathrm{IC}_{50}$ of $6.9 \pm 0.1 \mathrm{mg} / \mathrm{L}$ in ABTS radical scavenging assay. Petroleum ether extract was the less antioxidant extract. The decoction 
Citation: Babili FE, Valentin A, Chatelain C (2013) Lawsonia Inermis: Its Anatomy and its Antimalarial, Antioxidant and Human Breast Cancer Cells MCF7 Activities. Pharmaceut Anal Acta 4: 203. doi:10.4172/2153-2435.1000203

Page 5 of 6

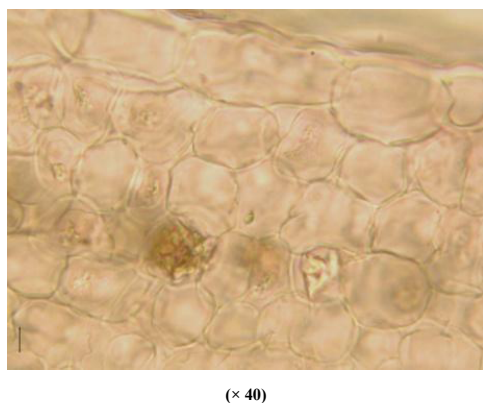

Figure 6: Lamina details: Crystals of calcium oxalate between palisade and spongy mesophyll.

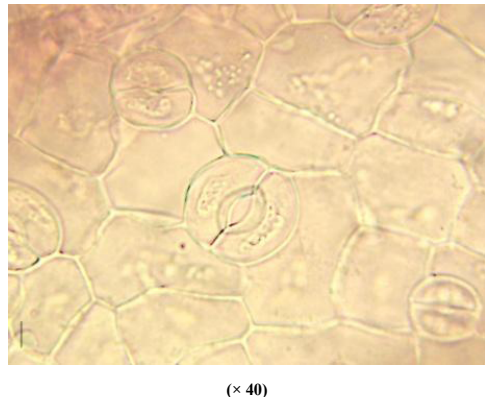

Figure 7: Sampling of inferior epidermis: Anomocytic stomata. Scale bars: (x 20): $2.3 \mu \mathrm{m},(x$ 40): $0.5 \mu \mathrm{m},(x 100): 0.07 \mu \mathrm{m}$.

\begin{tabular}{|l|l|l|l|l|}
\hline Type of extract & $\begin{array}{l}\text { Polyphenols } \\
\text { (eq Gallic }^{\text {acid) }}\end{array}$ & $\begin{array}{l}\text { Tannins } \\
\text { (eq } \\
\text { Catechin) }^{\mathbf{a}}\end{array}$ & $\begin{array}{l}\text { Flavonoids } \\
\text { (eq } \\
\text { Quercetin) }^{\mathbf{a}}\end{array}$ & $\begin{array}{l}\text { Anthocyanins } \\
\text { (eq cyanindin) }^{\mathbf{b}}\end{array}$ \\
\hline Ethyl acetate & $129.6 \pm 4.1$ & $477.9 \pm 12.9$ & $85.6 \pm 3.1$ & $0.75 \pm 0.02$ \\
\hline Petroleum ether & $71.7 \pm 2.1$ & $315.6 \pm 11.2$ & $52.9 \pm 1.9$ & $1.98 \pm 0.06$ \\
\hline Ethanol & $105.8 \pm 4.2$ & $58.1 \pm 1.7$ & $33.8 \pm 1.4$ & $5.48 \pm 0.17$ \\
\hline Decoction & $100.2 \pm 3.5$ & $31.3 \pm 0.8$ & $16.2 \pm 0.5$ & $1.86 \pm 0.05$ \\
\hline
\end{tabular}

a: $\mathrm{g} / \mathrm{Kg}$ dry; ${ }^{b}: \mathrm{mg} / \mathrm{Kg}$ dry

Table 1: Chemical composition of Henna extracts.

\begin{tabular}{|l|l|l|}
\hline Type of extract & $\begin{array}{l}\text { ABTS assay } \\
\mathbf{I C}_{\mathbf{5 0}}(\mathbf{m g} / \mathbf{L})\end{array}$ & $\begin{array}{l}\text { DPPH assay } \\
\mathbf{I C}_{\mathbf{5 0}}(\mathbf{m g} / \mathbf{L})\end{array}$ \\
\hline Ethyl acetate & $8.6 \pm 0.2$ & $29.5 \pm 0.8$ \\
\hline Petroleum ether & $738.7 \pm 9.6$ & $161.6 \pm 2.3$ \\
\hline Ethanol & $6.9 \pm 0.1$ & $14.1 \pm 0.5$ \\
\hline Decoction & $16.8 \pm 0.7$ & $13.0 \pm 0.6$ \\
\hline Vit C & $1.9 \pm 0.1$ & $4.4 \pm 0.2$ \\
\hline
\end{tabular}

Table 2: Henna extracts antioxidant activity.

\begin{tabular}{|l|l|l|}
\hline Type of extract & $\begin{array}{l}\text { Cytotoxic activity } \\
\mathbf{I C}_{\mathbf{5 0}}(\mathbf{m g} / \mathbf{L})\end{array}$ & $\begin{array}{l}\text { Antimalarial activity } \\
\mathbf{I C}_{\mathbf{5 0}}(\mathbf{m g} / \mathbf{L})\end{array}$ \\
\hline Petroleum ether & 22 & 27 \\
\hline Ethyl acetate & 27 & 33 \\
\hline Ethanol & 34 & 53 \\
\hline Chloroquine & $\mathrm{ND}$ & 0.031 \\
\hline Doxorubicin & 0.218 & $\mathrm{ND}$ \\
\hline
\end{tabular}

Table 3: Biological activity of Henna extracts.

was the most antioxidant extract with $\mathrm{IC}_{50}$ of $13.0 \pm 0.6 \mathrm{mg} / \mathrm{L}$ in DPPH and with $\mathrm{IC}_{50}$ of $16.8 \pm 0.7 \mathrm{mg} / \mathrm{L}$ in ABTS radical scavenging assay. Ethanol extract seems more active than decoction in ABTS radical scavenging assay, but the decoction was so strong in DPPH radical scavenging assay. These two forms were used in traditional medicine.

Given its ease of use, this result confirms the traditional use of "henna" in Morocco, thus highlighting its potential in health.

\section{Cytotoxicity and antimalarial activities}

We found an antiplasmodial activity (Table 3) against both FcB1-Columbia and FcM29-Cameroon strains of $P$. falciparum of the petroleum ether extract $(27 \mathrm{mg} / \mathrm{L})$ and ethyl extract $(33 \mathrm{mg} / \mathrm{L})$ of Henna. Which places our Henna extracts in the range of plants showing an interesting activity, knowing that beyond an $\mathrm{IC}_{50}$ of the $35.5 \mathrm{mg} / \mathrm{L}$ antimalarial activity is low. However, this is the first time we tested the antimalarial activity of Henna.

Henna showed, also for the first time an activity against human breast cancer cells (MCF7) of the ethyl acetate extract $(27 \mathrm{mg} / \mathrm{L})$ and petroleum extract $(22 \mathrm{mg} / \mathrm{L})$. Comparison of the plant extracts activity with those of chloroquine does not indicate that the bioactive compounds have a low activity, but were dilute in the whole extracts.

Because of antimalarial, antioxidant and cytotoxic activities of its extracts, $L$. Inermis is an interesting natural resource for cosmetic industry. In conclusion, our study can be considered as a report on the anatomical features and on antimalarial and antioxidant properties of extracts prepared from Henna. The present results may explain the traditional medicinal use of henna in Morocco. It seems interesting to isolate the molecules responsible for these potentials.

\section{References}

1. Lei G, Wang, Yi-jun, Yang, Zhao-xia (2004) College of Chemical Engineering, Qingdao University, Qingdao, Peop Rep China. Qingdao Daxue Xuebao, Gongcheng Jishuban 19: 37-42.

2. Kok AN, Ertekin V, Bilge $Y$, Işik AF (2005) An unusual cause of suicide: henna (Lawsonia inermis Linn.). J Emerg Med 29: 343-344.

3. Tommasi G (1920) Henna (Lawsonia inermis). Chemical constitution of lawsone. II - Gazzetta Chimica Italiana 50: 263-272.

4. Abd-el-Malek Y, El-Leithy MA, Reda FA, Khalil M (1973) Antimicrobia principles in leaves of Lawsonia inermis. Landwirtschaftliche und Technische Mikrobiologie 128: 61-67.

5. Bhardwaj DK, Jain RK, Jain BC, Mehta CK (1978) 1 Hydroxy 3,7 dimethoxy 6 acetoxyxanthone, a new xanthone from Lawsonia inermis. J Agric Food chem 17: $1440-14411$.

6. Chakrabartty, Tarakeswar, Poddar, Gurudas St, Pyrek, et al. (1982) Constituents of Indian medicinal plants. Phytochemistry (Elsevier) 21: 1814 1816.

7. Gupta, Sarita, Ali M, Alam M, Sarwar (1992) $24 \beta$-Ethylcholest-4-en-3 $\beta$-ol from the roots of Lawsonia inermis. Phytochemistry 31: 2558-2560.

8. Handa, Geeta, Kapil, Aruna, Sharma, et al. (1997) Lawnermis acid: a new anticomplementary triterpenoid from Lawsonia inermis seeds. Indian Journal of Chemistry 28: 252-256.

9. Siddiqui BS, Kardar MN (2001) Triterpenoids from Lawsonia alba Phytochemistry 58: 1195-1198.

10. Yogisha S, Samiulla DS, Prashanth D, Padmaja R, Amit A (2001) Trypsin inhibitory activity of Lawsonia inermis. Fitoterapia 73: 690-691.

11. Ali NA, Jülich WD, Kusnick C, Lindequist U (2001) Screening of Yemen medicinal plants for antibacterial and cytotoxic activities. J ethnopharmacology 74: $173-179$

12. Ali M, Grever MR (1998) A cytotoxic naphthoquinone from Lawsonia inermis Fitoterapia 69: 181-183.

13. Mirande $R$ (1920) Sur le carmin aluné et son emploi, combiné avec celui du vert d'iode, en Histologie végétale. CR Acad Sci 170: 197-199.

14. European Pharmacopoeia (in force), Ed. Maison Neuve SA, Moulins, les Metz. 
Citation: Babili FE, Valentin A, Chatelain C (2013) Lawsonia Inermis: Its Anatomy and its Antimalarial, Antioxidant and Human Breast Cancer Cells MCF7 Activities. Pharmaceut Anal Acta 4: 203. doi:10.4172/2153-2435.1000203

15. Speranza A, Calzoni GL (2005) Atlas de la structure des plantes Ed. Belin 125-203.

16. Folin O, Ciocalteu $\vee(1927)$ On tyrosine and tryptophane determination in proteins. J Biol Chem 73: 627-650.

17. Naczk M, Amarowicz R, Pink D, Shahidi F (2000) Insoluble condensed tannins of canola/rapeseed. J Agric Food Chem 48: 1758-1762.

18. Arvouet-Grand A, Vennat B, Pourrat A, Legret P (1994) Standardisation d'un extrait de propolis et identification des principaux constituants. J Pharm Belg 49: 462-468.

19. Cheng GW, Breen PJ (1992) Cell count and size in relation to fruit size among strawberry cultivars. J Am Soc Hort Sci 117: 946-950.

20. Blois MS (1958) Antioxidant determinations by the use of a stable free radical. Nature 181: 1199-1200.

21. Re R, Pellegrini N, Proteggente A, Pannala A, Yang M, et al. (1999) Antioxidant activity applying an improved ABTS radical cation decolorization assay. Free Radic Biol Med 26: 1231-1237.

22. Trager W, Jensen JB (1976) Human malaria parasites in continuous culture. J Parasitol 19: 484-486.
23. Benoit F, Valentin A, Pelissier Y, Diafouka F, Marion C, et al. (1996) In vitro antimalarial activity of vegetal extracts used in West African traditional medicine. Am J Trop Med Hyg 54: 67-71.

24. Lambros C, Vanderberg JP (1979) Synchronization of Plasmodium falciparum Erythrocytic Stages in culture. J Parasitol 65: 418-420.

25. Desjardins RE, Canfield CJ, Haynes JD, Chulay JD (1979) Quantitative assessment of antimalarial activity in vitro by a semiautomated microdilution technique. Antimicrob Agents Chemother 16: 710-718.

26. Munoz V, Sauvain M, Mollinedo P, Callapa J, Rojas I, et al. (1999) Antimalarial activity and cytotoxicity of (-)-roemrefidine isolated from the stem bark of Sparattanthelium amazonum. Planta Med 65: 448-449.

27. Ouattara Y, Sanon S, Traoré Y, Mahiou V, Azas N, et al. (2006) Antimalarial activity of Swartzia madagascariensis desv. (Leguminosae), Combretum glutinosum Guill. \& Perr. (Combretaceae) and Tinospora Bakis Miers. (Menispermaceae), Burkina Faso Medicinal Plants. Afr J Trad Cam Alt Med 3: 75-81.

28. Valentin A, Benoit-Vical F, Moulis C, Stanislas E, Mallie M, et al. (1997) In vitro antimalarial activity of penduline, a bisbenzylisoquinoline from Isopyrum thalictroides. Antimicrob Agents Chemother 41: 2305-2307. 